\title{
The case of inorganic hypersomnia treated with light therapy in the course of schizoaffective disorder
}

\author{
Przypadek hipersomnii nieorganicznej leczonej światłem \\ w przebiegu zaburzenia schizoafektywnego
}

\author{
Jolanta Masiak ${ }^{1} \mathrm{~A}, \mathrm{~B}, \mathrm{D}, \mathrm{E}, \mathrm{F}$, Elżbieta Masiak ${ }_{\mathrm{E}, \mathrm{F}}$, Katarzyna Ziniuk ${ }^{3}{ }_{\mathrm{B}, \mathrm{D}}$ \\ ${ }^{1}$ Samodzielna Pracownia Badań Neurofizjologicznych Katedry Psychiatrii UM w Lublinie \\ ${ }^{2}$ Katedra Psychoterapii i Psychologii Zdrowia KUL \\ ${ }^{3}$ Samodzielna Pracownia Badań Neurofizjologicznych Katedry Psychiatrii UM w Lublinie
}

\begin{abstract}
According to ICD 10, nonorganic hypersomnia is defined as "a condition of either excessive daytime sleepiness and sleep attacks (not accounted for by an inadequate amount of sleep) or prolonged transition to the fully aroused state upon awakening. When no definite evidence of organic etiology can be found, this condition is usually associated with mental disorders". The severe hypersomnia in the course of schizoaffective disorder is rather a rare phenomenon. The paper presents the case of 41-year-old female patient with severe hypersomnia during the course of the schizoaffective disorder. The course of hypersomnia was severe. The patient slept constantly day and night and was awoken by her family for about three-hour period of time. The duration of hypersomnia was about one year until the onset of treatment. The patient was successfully treated with light therapy that caused gradual resolution of the symptoms of hypersomnia. The patient is also treated as prior to the onset of hypersomnia with antipsychotics and the mood stabilizers for schizoaffective disorder. Since that time there were six-year-period of follow up when the patient was free of any symptoms of hypersomnia.
\end{abstract}

Keywords: nonorganic hipersomnia, schizoaffective disorder, treatment

\section{Streszczenie}

Nieorganiczna hipersomnia wg ICD10, to zaburzenie w którym występuje nadmierna senność w ciągu dnia i ataki snu, nie będące skutkiem zbyt krótkiego snu nocnego lub wydłużone przechodzenie do stanu czuwania po obudzeniu. Zaburzenie to często współwystępuje z innymi zaburzeniami psychicznymi. Hipersomnia rzadko występuje w przebiegu zaburzenia schizoafektywnego. Przedstawiono przypadek 41 letniej pacjentki z diagnozą zaburzenia schizoafektywnego i hipersomnii. Stan zdrowia somatycznego pacjentki nie wykazywał odchyleń od normy. Przebieg hipersomnii był wyjątkowo ciężki. Pacjentka poza trzema godzinami wybudzenia, które codziennie inicjowała rodzina, spała przez pozostałą część doby i trwało to około roku przed rozpoczęciem leczenia. Zastosowano leczenie światłem, które okazało się skuteczne i spowodowało ustąpienie objawów hipersomnii. Pacjentka jest stale leczona farmakologicznie, podobnie jak przed wystąpieniem hipersomnii, w związku z zaburzeniem schizoafektywnym. Mimo sześcioletniego już okresu obserwacji objawy hipersomnii nie pojawiły się ponownie.

Słowa kluczowe: nieorganiczna hipersomnia, zaburzenie schizoafektywne, leczenie

According to ICD 10, nonorganic hypersomnia is defined as "a condition of either excessive daytime sleepiness and sleep attacks (not accounted for by an inadequate amount of sleep) or prolonged transition to the fully aroused state upon awakening. When no definite evidence of organic etiology can be found, this condition is usually associated with mental disorders" [1]. The hypersomnia prevalence ranges from $5-15 \%$ in the general population [2,3]. Other authors [4] assess the number of patients with nonorganic hypersomnia treated in Sleep Disorders Clinic as $2 \%$ of the total population of treated patients. The daytime sedation during the neuroleptic treatment report $30-40 \%$ of patients with schizophrenia in the course of the treatment $[5,6]$.
This paper presents the case of a 41-year-old female patient with severe hypersomnia during the course of the schizoaffective disorder. The patient's family had a genetic history, five members of the family were diagnosed with the affective disorders: including patient's father and three brothers. The patient's father, diagnosed with bipolar disorder also shows tendency to excessive daytime sleepiness but severity of the sleepiness is less intense than in the case of his daughter. The patient was 18-year old when the onset of schizoaffective disorder occurred. In the clinical picture, the paranoid delusions and the depressive symptoms were the most prominent. In the course of the disease, refractory depressive episodes, manic episodes and psychotic symptoms have been pre- 
sented. The hypersomnia occurred 23 years after schizoaffective disorder had been diagnosed and lasted for a year before the light treatment had been initiated. What should be emphasized is the severity of symptoms of hypersomnia. The patient slept constantly day and night and was awoken by her family members only for food and other basic physiological needs. In total, she was awake only for about three hours in 24 hours period of time. In the morning, when she was regularly awoken, she felt sleepy and tired, and tried to fall asleep again immediately. According to the Epworth Sleepiness Scale [7], she had a maximum score - 24 points, there were no symptoms like cataplexy, sleep paralysis or hypnagogic hallucinations. Before the hypersomnia began, she had been treated for some years with the valproic acid, clozapine, flupentixol and fluoxetine without symptoms of hypersomnia. After the onset of hypersomnia, the dose of clozapine was lowered to $75 \mathrm{mg} /$ day, the doses of other medications were also lowered but that did not influence the severity of hypersomnia. At the same time her general medical condition was good. We could not establish any other factors that could initiate the hypersomnia in case of our patient. The patient was assessed in terms of the general medical condition and polysomnography. Yet, as it comes to the result of polysomnography (PSG) we should bear in mind that we could not stop the medication in our patient and however, the doses were lowered it could influence the record. We also recorded the night sleep which was only the part of the complete day and night sleep. Given those limitations we can state that some PSG parameters showed as follows: NREM Sleep Stage 1$20,6 \%$, NREM Sleep stage 2-21,85\%, NREM Sleep Stage 3$18,1 \%$, NREM Sleep stage 4-2,8\%, Sleep latency - $14 \mathrm{~min}$, REM latency-60,5 min, sleep efficiency-79,7\%. They differ from the general population norms, particularly percentage of stages 1 and 2 [7].

After those procedures the patient was treated in our therapeutic center with the light, the treatment was performed each morning for half an hour [Phototherpy lamp Fotovita type FV 10L, luminous flux density: $9500 \mathrm{~lx}$ in distance $50 \mathrm{~cm}$ ]. After fourteen days of the treatment, the symptoms of hypersomnia gradually decreased. Finally, the patient became alert and active twelve hours a day and presented normal activity. She started making plans. When discharged from our therapeutic center she was in the state of remission of symptoms of schizoaffective disorder and with normal circadian rhythm. Since that time there was a four years period of follow up during which the patient was free of any symptoms of hyper- somnia. Presently, the patient continues to be treated with antipsychotics (clozapine) and mood stabilizers and mostly is in the state of remission. The severe nonorganic hypersomnia can be diagnosed in that case.

To conclude, the treatment with light has proved to be a sufficient therapeutic option. It is likely that the hypersomnia in the case of a patient was associated with or was a form of a clinical manifestation of the depressive episode. Yet, it is surprising that hypersomnia occurred many years after the onset of the schizoaffective disorder.

\section{References:}

1. The ICD-10 Classification of Mental and Behavioural Disorders. Clinical descriptions anddiagnostic guidelines [online]. World Health Organization. [access: 4 March 2013]. Access in World Wide Web: <http://www.who.int/classifications/icd/en/bluebook.pdf;;

2. Partinen M., Hublin C. Epidemiology of sleep disorders. W: Kryger M.H., Roth T., Dement W.C. red. Principles and Practice of Sleep Medicine. Wyd. 4. Elsevier/Saunders, Philadelphia 2005; 626-647.

3. 3.Szelenberger W., Skalski M. Epidemiologia zaburzeń snu w Polsce. Doniesienie wstępne. W: Nowicki Z., Szelenberger W. (red.). Zaburzenia snu. Diagnostyka i leczenie, wybrane zagadnienia. Biblioteka Psychiatrii Polskiej. Biblioteka Psychiatrii Polskiej Kraków 1999; 57-63.

4. Walacik E., Fornal M., Szelenberger W. Cechy osobowości pacjentów z hipersomnią nieorganiczną. Sen 2007; 7 : 1-7.

5. Wichniak A., Waliniowska E., Wierzbicka A., Czasak K., Musińska I., Szatkowska E., Jernajczyk W., Jarema M. Jakość snu i senność w ciągu dnia w zaburzeniach psychotycznych z kręgu schizofrenii w trakcie leczenia lekami przeciwpsychotycznymi. Psychiatria Polska 2009; 43(2) : 193-202.

6. Saletu B., Anderer P., Saletu-Zyhlarz G.M. Nonorganic hypersomnia: epidemiology, diagnosis, and therapy. Wiener Medizinische Wochenschrift 2001; $113: 266-77$.

7. Johns M.W. A new method for measuring daytime sleepiness: the Epworth sleepiness scale. Sleep, 1991;14(6) : 540-545.

8. Ekiert, H., and W. Jernajczyk. "Normy wzorca eeg snu dla zdrowej populacji polskiej w wieku 20-59 lat. Psychiatria Polska 1992; 26: 501-501.

\section{Correspondence address}

Jolanta Masiak

Samodzielna Pracownia Badań Neurofizjologicznych Katedry Psychiatrii UM w Lublinie

Głuska 1

20-439 Lublin

Tel. 817453887

mail: jolantamasiak@wp.pl

Otrzymano: 09.06.2015

Zrecenzowano: 14.07.2015

Ponownie zrecenzowano: 01.12.2015

Otrzymano po poprawie: 20.01.2016

Przyjęto do druku: 02.02.2016 